\title{
Nutritional value of school meals and their contributions to energy and nutrient intakes of rural school children in Enugu and Anambra States, Nigeria
}

Rufina N. B. Ayogu ${ }^{1 *}$, Paul E. Eme1, Vivien C. Anyaegbu', Henrietta N. Ene-Obong ${ }^{2}$ and Uche V. Amazigo ${ }^{3}$

\begin{abstract}
Background: Nutritional deficiencies among school children may hinge on inadequate nutrient intake. School meals should improve nutrient intakes by providing a third of recommended daily energy and nutrient intakes (RNI). The study aimed at evaluating school meals served in three rural schools to determine if they met one third of the RNI of the children. This will enhance meal planning.

Methods: Food samples $(20 \mathrm{~g})$ that constituted the school meals were collected for five consecutive days from three schools where school lunch programme was implemented. These were put in labelled small air tight plastic containers and stored in deep freezers in the Department of Home Science, Nutrition and Dietetics, University of Nigeria, Nsukka. The samples were analysed chemically using standard methods. Portion sizes of foods were obtained and the contributions made by these meals to the children's RNI were calculated. Results were presented in percentages and means \pm standard deviations.
\end{abstract}

Results: The results showed that energy value of the meals ranged from $32.27-243.4 \mathrm{Kcal} / 100 \mathrm{~g}$. The school meals contained carbohydrate $(0.7-48.4 \mathrm{~g})$, protein $(0.69-12.6 \mathrm{~g})$, vitamin C (0.7 - $8.22 \mathrm{mg})$, vitamin A (3.0 - $255.5 \mathrm{RE})$, iron $(0.05-1.7 \mathrm{mg})$, calcium $(3.0-120 \mathrm{mg})$ and zinc $(0.14-3.0 \mathrm{mg})$ per $100 \mathrm{~g}$ of food consumed. They contributed $16.4-25$. 5\% energy, 53.4 - 116.9\% protein, 66.0 - 159.5\% vitamin A, $37.3-45.7 \%$ vitamin C, $13.2-28.5 \%$ calcium, $5.9-20.6 \%$ iron and $35.1-92.9 \%$ zinc to the children's daily requirements.

Conclusion: The school meals provided over one third of the RNI for protein, vitamins A and C, and zinc but did not meet a third of the RNI for energy, calcium and iron.

Keywords: Contributions, School meals, RNI, Energy and nutrient intakes, Rural school children, Enugu state, Anambra state, Nigeria

\section{Background}

The high prevalence of under nutrition in developing countries of the world has triggered many intervention strategies to ameliorate these conditions which have been found to have huge consequences on the affected individuals, their families and the nation as a whole. One of such strategies with focus on school children is school health programme which incorporates school

\footnotetext{
* Correspondence: rufina.ayogu@unn.edu.ng

${ }^{1}$ Department of Home Science, Nutrition and Dietetics, University of Nigeria, Nsukka, Nigeria

Full list of author information is available at the end of the article
}

meal/lunch. School meal programme ensures that the school child receives one nutritious mid day meal every school day to grow and develop adequately. The ubiquity of school feeding programmes suggests that these programmes are indeed appropriate candidates for a rapid safety net response [1]. Household meals in most low- and middle-income countries have been observed to be inadequate in energy, animal protein and micronutrients. School meals therefore complement what school children in these homes receive. Bundy et al. [1] explained that there are very few studies that compare in-school feeding with take-home rations in similar 
settings, and the few that have gone further with this suggest that both programmes lead to similar improvements over having no programme at all.

School-aged children require adequate food in both quantity and quality to stay healthy. Provision of energy, immunity, regulation of body processes, repair and maintenance of body tissues can only be achieved through adequate food intake. Snacks consumed in-between meals also add to total food intake necessary to meet the recommended daily energy and nutrient intakes of school children. From a health promotion approach, the quality and amount of food and beverages consumed while at school have an enormous potential impact on the health and well-being of young people [2]. They are active and often require more calories and nutrients in comparison with their body sizes.

Breakfast skipping is common among school children $[3,4]$ for many reasons such as lack of food and time to consume what is available [4]. School period lasts $6-8 \mathrm{~h}$ daily and the children are expected to endure hunger throughout this period. When hungry, one finds it difficult to cope with school activities hence the need for school meals. School meals alleviate short term hunger, and provide energy and nutrients for growth and development of the school aged child. Adequate nutrition guarantees better health status and ensures sustained attention span for better academic performances. Access to a nutritious breakfast and mid-day meal is a very important determinant of the nutritional status as well as the overall well-being and cognitive development of school children. Healthier and better nourished children stay in school longer, learn more and later become healthier and more productive adults [5].

Enugu State is one of the 13 states where the Federal Government of Nigeria implemented school feeding programme in 2004 using locally grown foods. With the collapse of the programme in the State, school children in the State were further exposed to nutritional challenges. Among 5 - 12year-old school children in Enugu State, Ejekwu et al. [6] reported that $27.7 \%$ were stunted, $29.9 \%$ were underweight and $25.5 \%$ were wasted and showed that rural children were significantly $(P<0.05)$ more stunted than those in the urban areas. Nwamara et al. [7] also reported stunting (19.5\%), wasting (8.9\%), underweight $(8.5 \%)$ and iodine deficiency (3.8\%) among primary school children in Okpuje, Nsukka Local Government Area (LGA) of Enugu State. In Anambra State, prevalence of underweight and stunting among primary school pupils were reported as 10.7 and $1.9 \%$, respectively [8]. Ukegbu (4) reported that 15.9, 27.4 and $20.7 \%$ of primary school children in Orumba North LGA of Anambra State were underweight, stunted and wasted, respectively. Indicators of anthropometric and micronutrient status among school children in various parts of Nigeria [9-14] indicate that school children's nutritional status is substandard and unsatisfactory.
In the light of this, a non - governmental, not-forprofit organisation, Pan African Community Initiative on Education and Health (PACIEH) adopted a communitymanaged strategy [15] to improve the health, nutrition and education of school children in three rural schools in Enugu and Anambra States of Nigeria. It currently feeds 719 pupils every school day with funds provided by Heineken African Foundation (through Nigeria Breweries PLC), PACIEH, Enugu State Universal Basic Education Board (ENSUBEB) and TruValue). The menu was altered a few times to what is shown in this study to improve nutrient intakes while contending with frequent increase in the cost of food items. The change of menu necessitated this study aimed at evaluating the nutritional value of the meals consumed by the school children and determining the contributions they made to the recommended daily energy and nutrient intakes of the children. This would enhance review of the school menu for better energy and nutrient intakes. It would also inform policy makers on school meal planning.

\section{Methods \\ Study area}

The study took place in June, 2015 at Eke Central Primary School and Oma-Eke Community Primary School both in Udi LGA of Enugu State and at Central/Salvation Primary School Afor-agu, Abatete in Idemili North LGA of Anambra State, Nigeria. These are remote resource poor communities. The parents of the pupils and the School Based Management Committee (SBMC) played a major role in determining the menu at each school. This is based on the foods available in the community. Each of the three schools has school kitchen (built by PACIEH and partners) where the foods were cooked centrally by trained volunteer female cooks who were parents of the school children. Primary training of the cooks took place before the commencement of the feeding programme in 2013 and subsequent retraining was given at the beginning of each school year. The training involved both theory and practical demonstrations on measurements of food items, food preparation, portion sizes and personal, environmental and food hygiene practices. The cooks also shared the foods to the children in their classrooms between 10.30 and 11.30 am every school day. The meals were common to all the children.

\section{Ethics approval and consent to participate}

A meeting was held with the School Based Management Committee (SBMC) and Parents Teachers' Association (PTA) of the schools and the objective of the study explained to them and their consent obtained. The children gave oral consent for their foods to be weighed. PACIEH and partners (Enugu State Universal Basic Education Board (ENSUBEB) and Ministry of Education) approved the study. 


\section{Collection of food samples}

Samples $(20 \mathrm{~g})$ of each cooked food were collected individually from each of the three primary schools on 5 consecutive schools days. Bread, yogurt, milk, eggs and pap were not collected for analysis; their values in the West African Food Composition Table (FCT) [16] were used for computation. The samples were preserved in labelled small air tight plastic containers and stored in a deep freeze $\left(-20{ }^{\circ} \mathrm{C}\right)$ in the Diet Therapy Laboratory of the Department of Home Science, Nutrition and Dietetics, University of Nigeria, Nsukka until analysis.

\section{Chemical analyses of the school meal}

Triplicate determinations of proximate and micronutrient compositions of the school meals were carried out at the analytical laboratory of the Department of Home Science, Nutrition and Dietetics by the methods described by Association of Analytical Chemists (AOAC) [17]. Micro-Kjeldahl method was used for protein, dry ashing for ash, soxhlet extraction method for fat, hot air oven method for moisture, acid hydrolysis for crude fibre and carbohydrate was determined by difference. Atomic absorption Sphectrophotometric method was employed for mineral (iron, zinc and calcium) and vitamin (vitamin $\mathrm{A}$ and $\mathrm{C}$ ) determinations. The nutrient values of foods not analyzed were obtained from West African Food Composition Table (FCT) [16] and used in calculating the contributions to energy and nutrient intakes made by such foods. Atwater conversion factor [18] was used in the determination of the energy values of the foods.

\section{Determination of portion sizes of the meals consumed by the pupils}

Portion sizes refer to the quantity of food consumed. Determination of the portion sizes was carried out for every school child (719) in each of the schools on all 5 school days of the week. These were presented according to the foods consumed by the school children.

Four stages were involved:

i. An empty plate was weighed for each school child.

ii. Food was added to the plate and the weight recorded.

iii. The children were given the food to eat and after eating, any leftover in the plate as well as any waste were weighed.

iv. The weight of the leftover food and wastes were subtracted from the quantity served each child to obtain the actual quantity of food consumed (food intake).

\section{Determination of nutrient intake}

This was determined by simple proportion. Results of nutrient analysis carried out by laboratory analysis or obtained from FCT per $100 \mathrm{~g}$ and portion sizes in grams were used to obtain the value of nutrients consumed over a period of five school days. For example, if $100 \mathrm{~g}$ of steamed bambara groundnut pudding contained X $\mathrm{g}$ of protein and the portion size consumed was $200 \mathrm{~g}$, then the protein value consumed $=\left(\frac{X}{100} \times \frac{200}{1}\right) g$ protein.

This was done for all the nutrients involved in the study and the mean intake supplied by the school meal was obtained by dividing the values by 5 (days).

\section{Statistical analysis}

Data generated from the study were analysed using Statistical Package for Social Sciences (SPSS) version 16. Descriptive statistics were used and results were presented in percentages, means and standard deviations. Analysis of variance was used in data analysis and Duncan's New Multiple Range test was used to separate and compare the means with significance set at $P<0.05$.

\section{Results}

Characteristics of the subjects and the school meals

The school children were aged $2-5$ years $(33.0 \%), 6$ 9 years (34.1\%), $10-14$ years (29.1\%), and $15-18$ years (3.8\%). Boys constituted $52.6 \%$ while $47.4 \%$ were girls. Those in Early Child Centres (ECC) were $36.2 \%$ whereas $63.8 \%$ were in primary schools. The school meal consisted of jollof rice and beans with vegetables and a finger of banana (consumed twice weekly); steamed cowpea pudding (moi-moi) consumed with yogurt and pap (fermented maize paste) mixed with cocoa (richoco) powder; steamed bambara groundnut pudding with pap (fermented maize paste) mixed with cocoa (richoco) powder; and bread, egg with cow milk (Fig. 1). School children at Abatete School did not consume yogurt but soya bean milk.

\section{Portion sizes of foods consumed}

Table 1 shows the mean portion sizes of the foods consumed by the children by age and schools. In all the 3 schools, the portion sizes consumed by the $2-5$-year-olds were the smallest and significantly $(P<0.05)$ differed from the portion sizes of the other 3 older age groups. The portion sizes of most foods consumed by the $10-14$ and $15-$ 18 -year-olds in all the schools were comparable $(P>0.05)$. The quantity of pap mixed with cocoa powder and steamed bambara groundnut pudding (okpa) ranged from 170 to $220 \mathrm{~g}$ with the $10-14$ and $15-18$ years having significantly $(P<0.05)$ higher quantities. The quantity of steamed cowpea pudding (moi-moi) consumed by pupils ranged 


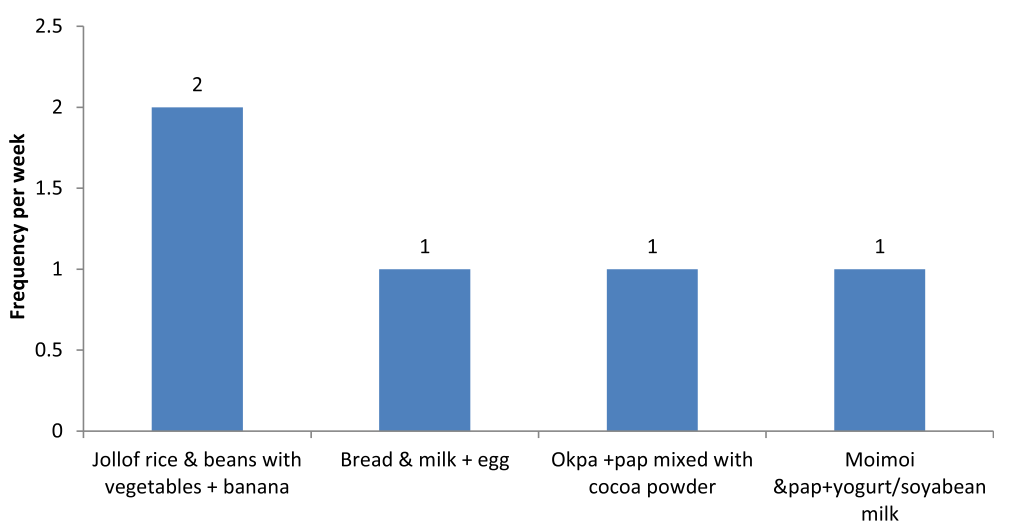

Fig. 1 Types and frequency of consumption of school meals in a week

from 170 to $230 \mathrm{~g}$; those aged 15 - 18 years had significantly $(P<0.05)$ higher portion sizes than the other age groups. The amount of bread consumed by the children ranged from 65 to $85 \mathrm{~g}$ with pupils of $6-9$ years at Eke Central Primary School having a significantly $(P<0.05)$ higher quantity than others. The weight of egg consumed by the children ranged from 70 to $85 \mathrm{~g}$ and jollof rice and beans with banana ranged from 210 to $440 \mathrm{~g}$; the 15 - 18year-olds at Oma-Eke Community Primary School and Abatete Primary School had significantly $(P<0.05)$ larger portion sizes in comparison with other age groups. The quantity of cow milk and soya bean milk consumed by the pupils ranged from 180 to $240 \mathrm{ml}$, respectively; children (15 - 18 years) at Abatete had the highest quantity $(P<0.05)$ of both. Yogurt ranged from 180 to $220 \mathrm{ml}$; the 15 - 18-year-old pupils at Eke Central Primary School had the largest portion size $(P<0.05)$.

\section{Nutrient compositions of the school meals}

The nutrient compositions of the meals consumed in the 3 schools are shown in Table 2. Egg had the highest value of protein $(12.6 \mathrm{~g})$, fat $(9.5 \mathrm{~g})$ and iron $(1.7 \mathrm{~g})$. Bread had the highest carbohydrate $(48.4 \mathrm{~g})$ and energy $(243.4 \mathrm{Kcal})$ values. The highest vitamin A value was found in okpa (steamed bambara groundnut pudding) consumed at Eke (255.5 RE) while the highest vitamin C (8.2 mg) was found in steamed cowpea pudding (moi-moi) consumed at OmaEke. Yogurt (118.0 mg) and steamed bambara groundnut pudding $(60.0 \mathrm{mg})$ were superior to other foods in calcium. Rice and beans consumed at Oma-Eke proved superior in zinc to other foods consumed in all the schools.

\section{Energy and nutrient intakes of the school children}

The energy and nutrient intakes of the school children and the percentage of energy from the energy giving nutrients are shown in Table 3. In all the schools, the intakes increased with age with the $2-5$-year-olds having the least $(P<0.05)$ intakes. Carbohydrate was the main source of energy from the school meals with protein and fat making similar contributions to energy intake. Protein intake ranged from 18.11 - $27.27 \mathrm{~g}$ and carbohydrate ranged from $50.28-$ $71.31 \mathrm{~g}$. Fat and energy intakes ranged from $8.78-14.86 \mathrm{~g}$ and from 357.01 - $513.72 \mathrm{kcal}$, respectively. Vitamin A intake ranged from 214.75 - $353.75 \mathrm{RE}$ while vitamin $\mathrm{C}$ ranged from $11.45-17.87 \mathrm{mg}$. Calcium intake had a range of $132.90-215.81 \mathrm{mg}$; iron was $1.41-2.16 \mathrm{mg}$ and the intake of zinc ranged from 2.10 to $5.90 \mathrm{mg}$.

\section{Percentage contributions of school meals to RNI}

The contributions made by the school meals to the recommended nutrient and energy intakes of the school children in the 3 schools are presented in Table 4. The percentage of recommended energy and nutrient intakes met by the school meals consumed at Eke Central Primary School were protein $(57.7$ - 116.9\%), energy (16.4 - 23.0\%), calcium (16.3 - 28.5\%), iron (7.2 - 20.6\%), zinc (47.5 - 69.6\%), vitamins A (82.7 - 150.4\%) and C (37.3 - 38.2\%). At Oma-Eke Community Primary School, the school meals provided $17.5-23.9 \%$ energy, $53.4-107.0 \%$ protein, $84.7-159.5 \%$ vitamin A, 67.6 - 92.9\% zinc, 14.5 - 25.3\% calcium, 5.9 $15.7 \%$ iron and $42.0-45.7 \%$ vitamin C. The contributions of the school meals at Abatete were energy (18 - 24.3\%), protein $(58-103.1 \%)$, vitamin A $(66.0-127.4)$, vitamin C (42.8 - 45.1\%), zinc (35.1 - 45.4\%), calcium $(13.2-22.8 \%)$ and iron $(7.4-19.3 \%)$.

\section{Discussion}

This study aimed to assess the energy and nutrient composition of school meals served in 3 schools in Enugu and Anambra States of Nigeria and their contributions to energy and nutrient intakes of school children. It showed that pulses were consumed on 4 days out of five school days in a week. Cowpeas and bambara groundnuts are among the pulses recognized by Food and Agriculture Organization (FAO) [19] because of their contributions to protein and micronutrient intakes of individuals. Pulses typically contain 
Table 1 Portion sizes of school meals consumed by the school children by age and schools

\begin{tabular}{|c|c|c|c|c|}
\hline \multirow[b]{2}{*}{ Variables } & \multicolumn{4}{|l|}{ Age groups } \\
\hline & $2-5$ years $(N=231)$ & $6-9$ years $(N=239)$ & $10-14$ years $(N=204)$ & $15-18$ years $(N=26)$ \\
\hline Eke Central Primary School $(N=324)$ & $N=106$ & $N=86$ & $N=130$ & $N=2$ \\
\hline Pap + richoco (g) & $175^{\mathrm{a}} \pm 1.22$ & $195^{b} \pm 0.99$ & $220^{c} \pm 0.88$ & $220^{c} \pm 0.46$ \\
\hline Okpa (g) & $170^{\mathrm{a}} \pm 2.46$ & $190^{\mathrm{b}} \pm 1.99$ & $220^{c} \pm 1.06$ & $220^{c} \pm 0.96$ \\
\hline Bread (g) & $65^{a} \pm 0.79$ & $85^{\complement} \pm 0.71$ & $80^{b} \pm 0.86$ & $80^{b} \pm 0.61$ \\
\hline Egg (g) & $70^{a} \pm 1.73$ & $70^{\mathrm{a}} \pm 1.43$ & $80^{b} \pm 0.20$ & $80^{b} \pm 0.18$ \\
\hline Milk (ml) & $190^{\mathrm{a}} \pm 0.57$ & $220^{\mathrm{b}} \pm 0.51$ & $220^{b} \pm 0.49$ & $220^{\mathrm{b}} \pm 0.40$ \\
\hline Moi-moi (g) & $170^{\mathrm{a}} \pm 2.36$ & $210^{\mathrm{b}} \pm 2.08$ & $220^{c} \pm 1.96$ & $230^{\mathrm{d}} \pm 1.89$ \\
\hline Yoghurt (ml) & $180^{\mathrm{a}} \pm 0.91$ & $190^{\mathrm{b}} \pm 0.89$ & $210^{\complement} \pm 1.85$ & $220^{d} \pm 1.81$ \\
\hline${ }^{\mathrm{C}}$ Rice $\&$ beans jollof+vegetables ( $\mathrm{g}$ ) & $240^{a} \pm 0.33$ & $280^{b} \pm 0.33$ & $350^{d} \pm 1.29$ & $340^{c} \pm 0.22$ \\
\hline Oma-Eke CPS $(N=170)$ & $N=41$ & $N=78$ & $N=50$ & $N=1$ \\
\hline Pap + richoco (g) & $170^{\mathrm{a}} \pm 2.12$ & $200^{b} \pm 0.99$ & $220^{d} \pm 1.07$ & $210^{c} \pm 0.98$ \\
\hline Okpa (g) & $170^{\mathrm{a}} \pm 0.32$ & $220^{\mathrm{b}} \pm 0.33$ & $220^{\mathrm{b}} \pm 0.42$ & $220^{\mathrm{b}} \pm 0.30$ \\
\hline Bread (g) & $70^{a} \pm 3.31$ & $75^{\mathrm{ab}} \pm 2.98$ & $80^{\mathrm{b}} \pm 2.07$ & $80^{b} \pm 1.99$ \\
\hline Egg (g) & $70^{a} \pm 4.38$ & $70^{a} \pm 4.02$ & $75^{\mathrm{ab}} \pm 3.99$ & $85^{b} \pm 3.09$ \\
\hline Milk (ml) & $180^{\mathrm{a}} \pm 1.88$ & $205^{b} \pm 1.02$ & $210^{b c} \pm 0.99$ & $215^{\complement} \pm 0.90$ \\
\hline Moi-moi (g) & $170^{\mathrm{b}} \pm 2.68$ & $192^{b} \pm 2.01$ & $215^{c} \pm 1.97$ & $210^{c} \pm 1.08$ \\
\hline Yoghurt (ml) & $180^{\mathrm{a}} \pm 2.90$ & $180^{\mathrm{a}} \pm 2.86$ & $190^{\mathrm{b}} \pm 1.82$ & $190^{b} \pm 1.77$ \\
\hline${ }^{\mathrm{C}}$ Rice \& beans jollof+vegetables ( $\mathrm{g}$ ) & $210^{\mathrm{a}} \pm 2.99$ & $282^{b} \pm 2.12$ & $340^{\complement} \pm 2.01$ & $348^{\mathrm{C}} \pm 1.99$ \\
\hline Abatete C/SA PS $(N=206)$ & $N=84$ & $N=75$ & $N=24$ & $N=23$ \\
\hline Pap + richoco (g) & $170^{\mathrm{a}} \pm 1.72$ & $200^{\mathrm{b}} \pm 0.87$ & $220^{c} \pm 0.07$ & $220^{c} \pm 0.04$ \\
\hline Okpa (g) & $180^{\mathrm{a}} \pm 0.78$ & $220^{\mathrm{b}} \pm 0.88$ & $220^{b} \pm 0.81$ & $220^{\mathrm{b}} \pm 0.01$ \\
\hline Bread (g) & $70^{\mathrm{a}} \pm 1.88$ & $70^{\mathrm{a}} \pm 0.79$ & $80^{b} \pm 0.11$ & $80^{b} \pm 0.16$ \\
\hline Egg (g) & $70^{a} \pm 1.43$ & $70^{\mathrm{a}} \pm 1.43$ & $70^{\mathrm{a}} \pm 1.43$ & $70^{\mathrm{a}} \pm 1.43$ \\
\hline Milk (ml) & $180^{\mathrm{a}} \pm 0.57$ & $210^{\mathrm{b}} \pm 0.88$ & $220^{\complement} \pm 0.88$ & $240^{d} \pm 0.02$ \\
\hline Moi-moi (g) & $170^{\mathrm{a}} \pm 2.36$ & $200^{\mathrm{b}} \pm 0.92$ & $220^{c} \pm 0.51$ & $220^{c} \pm 0.19$ \\
\hline Soya bean milk (ml) & $180^{\mathrm{a}} \pm 0.91$ & $210^{b} \pm 0.92$ & $210^{\mathrm{b}} \pm 0.42$ & $240^{c} \pm 0.18$ \\
\hline${ }^{\mathrm{C}}$ Rice \& beans jollof+vegetables ( $\mathrm{g}$ ) & $260^{a} \pm 0.06$ & $340^{b} \pm 0.45$ & $420^{c} \pm 0.24$ & $440^{d} \pm 0.11$ \\
\hline
\end{tabular}

Abatete C/SA PS Abatete Central/Salvation Army Primary School, Oma-Eke CPS Oma-Eke Community Primary School, Richoco Cocoa powder from Cadbury, Okpa Steamed Bambara groundnut pudding, Moi-moi Steamed cowpea pudding, Pap Maize paste prepared in hot water

${ }^{\mathrm{C}}$ This was consumed with a finger of banana

Values with different superscripts in the same row are significantly $(P<0.05)$ different

Values are means \pm standard deviations

about twice the amount of protein found in whole grain cereals and are rich sources of vitamins, iron, zinc, magnesium, bioactive compounds and gives a better protein quality when consumed with cereals $[19,20]$.

Portion sizes of the school meals consumed by the pupils In all the 3 schools, the portion sizes consumed by the 2 - 5-year olds were the smallest. This was expected because they cannot consume a quantity that is beyond their gastric capacity. A study showed that the intake of young children remained the same irrespective of the portion size served [21]. This implies that large portion sizes are not necessary for these children rather the emphasis should be on nutrient dense portion sizes.

\section{Energy and nutrient composition of the school meals}

The nutrient compositions of the foods per $100 \mathrm{~g}$ were in line with the results reported by other researchers [4, 22, 23] on similar foods. These nutrients build and maintain healthy tissues; aid body processes, protect the body against infections and diseases; and provide energy for work [24]. Several dietary components have been identified as having positive effects on cognitive abilities. Dietary factors such as iron, zinc, copper, vitamins B, D, $\mathrm{E}, \mathrm{C}$ and carotenes can affect multiple brain processes 


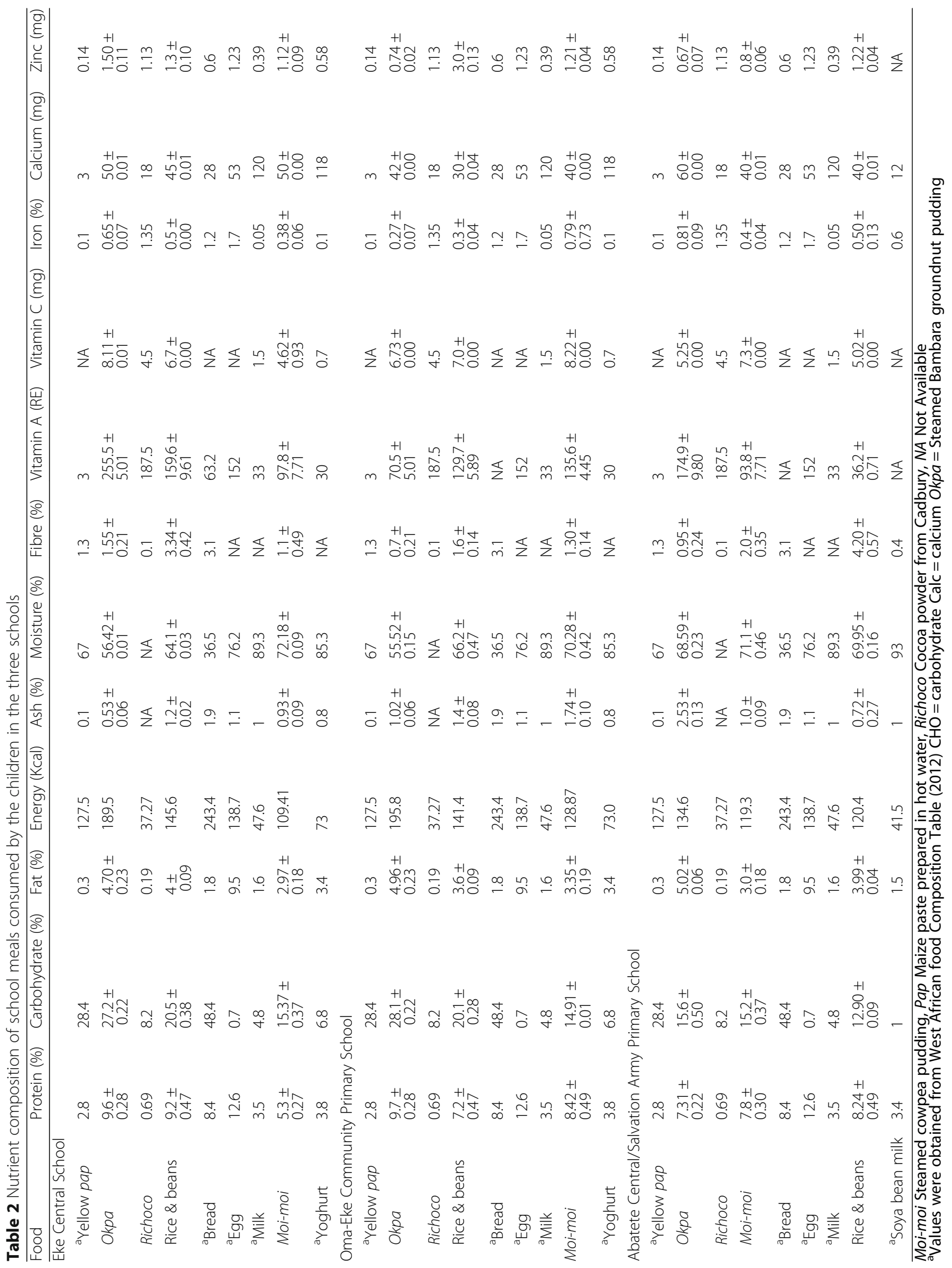


Table 3 Nutrient and energy intakes of the school children and percentage of energy from the energy giving nutrients

\begin{tabular}{|c|c|c|c|c|c|c|c|c|c|}
\hline $\begin{array}{l}\text { Schools/ } \\
\text { Age groups }\end{array}$ & $\begin{array}{l}\text { Protein (g) } \\
\text { (\% energy) }\end{array}$ & $\begin{array}{l}\text { Carbohydrate (g) } \\
\text { (\% energy) }\end{array}$ & $\begin{array}{l}\text { Fat (g) } \\
\text { (\% energy) }\end{array}$ & $\begin{array}{l}\text { Energy } \\
\text { (Kcal) }\end{array}$ & $\begin{array}{l}\text { Vitamin A } \\
(\mathrm{mg})\end{array}$ & $\begin{array}{l}\text { Vitamin C } \\
(\mathrm{mg})\end{array}$ & $\begin{array}{l}\text { Calcium } \\
(\mathrm{mg})\end{array}$ & $\begin{array}{l}\text { Iron } \\
\text { (mg) }\end{array}$ & $\begin{array}{l}\text { Zinc } \\
\text { (mg) } \\
\end{array}$ \\
\hline $6-9$ years & $23.47^{\mathrm{b}}(22.4)$ & $58.18^{\mathrm{ab}}(55.5)$ & $10.32^{\mathrm{b}}(22.1)$ & $410.58^{b}$ & $300.78^{b}$ & $13.07^{\mathrm{ab}}$ & $193.79^{b}$ & $1.88^{\mathrm{a}}$ & $3.57^{\mathrm{a}}$ \\
\hline $10-14$ years & $26.80^{\complement}(22.8)$ & $64.42^{\mathrm{bc}}(54.8)$ & $11.69^{\complement}(22.4)$ & $439.24^{c}$ & $330.71^{c}$ & $15.12^{b}$ & $212.61^{c}$ & $2.08^{\mathrm{b}}$ & $4.09^{b}$ \\
\hline $15-18$ years & $27.10^{c}(22.7)$ & $65.39^{\complement}(54.9)$ & $11.86^{\mathrm{C}}(22.4)$ & $466.91^{d}$ & $335.82^{c}$ & $15.23^{b}$ & $215.81^{c}$ & $2.09^{b}$ & $4.11^{\mathrm{b}}$ \\
\hline \multicolumn{10}{|c|}{ Oma-Eke Community Primary School } \\
\hline $2-5$ years & $18.81^{\mathrm{a}}(20.4)$ & $52.23^{\mathrm{a}}(56.8)$ & $9.32^{\mathrm{a}}(22.8)$ & $369.43^{\mathrm{a}}$ & $261.48^{\mathrm{a}}$ & $12.64^{\mathrm{a}}$ & $154.70^{\mathrm{a}}$ & $1.41^{\mathrm{a}}$ & $4.23^{\mathrm{a}}$ \\
\hline $6-9$ years & $22.90^{\mathrm{b}}(20.3)$ & $64.60^{\mathrm{b}}(57.3)$ & $11.24^{\mathrm{ab}}(22.4)$ & $452.80^{b}$ & $318.98^{b}$ & $16.01^{b}$ & $176.84^{\mathrm{b}}$ & $1.62^{b}$ & $5.20^{b}$ \\
\hline $10-14$ years & $25.10^{\complement}(20.3)$ & $71.09^{\mathrm{C}}(57.4)$ & $12.31^{b c}(22.3)$ & $497.42^{c}$ & $338.74^{\mathrm{bc}}$ & $17.79^{b}$ & $188.99^{c}$ & $1.73^{\mathrm{c}}$ & $5.90^{\mathrm{b}}$ \\
\hline $15-18$ years & $25.10^{\complement}(20.2)$ & $71.31^{c}(57.3)$ & $12.47^{\mathrm{bc}}(22.5)$ & $497.87^{c}$ & $353.75^{c}$ & $17.68^{b}$ & $190.60^{c}$ & $1.72^{c}$ & $5.87^{\mathrm{b}}$ \\
\hline \multicolumn{10}{|c|}{ Abatete Community Primary School } \\
\hline $2-5$ years & $18.11^{\mathrm{a}}(20.1)$ & $52.09^{\mathrm{a}}(57.9)$ & $8.78^{\mathrm{a}}(22.0)$ & $359.82^{\mathrm{a}}$ & $214.75^{\mathrm{a}}$ & $13.50^{\mathrm{a}}$ & $132.90^{\mathrm{a}}$ & $1.74^{\mathrm{a}}$ & $2.10^{a}$ \\
\hline $6-9$ years & $22.33^{\mathrm{b}}(20.6)$ & $62.31^{b}(57.4)$ & $10.62^{\mathrm{ab}}(22.0)$ & $434.14^{b}$ & $254.84^{\mathrm{b}}$ & $15.28^{\mathrm{a}}$ & $159.98^{b}$ & $2.08^{b}$ & $2.54^{\mathrm{b}}$ \\
\hline $10-14$ years & $24.43^{\mathrm{ab}}(20.7)$ & $67.85^{\mathrm{bc}}(57.4)$ & $11.48^{\mathrm{ab}}(21.0)$ & $472.18^{c}$ & $265.70^{c}$ & $17.87^{\mathrm{b}}$ & $171.18^{c}$ & $2.14^{\mathrm{b}}$ & $2.79^{\mathrm{b}}$ \\
\hline $15-18$ years & $27.27^{\mathrm{C}}(20.8)$ & $70.15^{\mathrm{C}}(53.6)$ & $14.86^{\mathrm{b}}(25.6)$ & $513.72^{d}$ & $264.16^{c}$ & $17.12^{b}$ & $172.24^{c}$ & $2.16^{\mathrm{b}}$ & $3.02^{c}$ \\
\hline
\end{tabular}

Values with different superscripts in the same column for each school are significantly $(P<0.05)$ different

by regulating neurotransmitter pathways, synaptic transmission, membrane fluidity and signal-transduction pathways [25]. This implies that school children can benefit physically and cognitively from school meals. This benefit spans from the nutrients in the meals and its ability to add to total energy and nutrient intakes.

\section{Energy and nutrient intakes of the school children}

In all the schools, the intakes increased with age with the $2-5$-year-olds having the lowest intakes. This is in line with the portion sizes consumed. It was not surprising that the energy and nutrient intakes of the children increased with age since the portion sizes had similar trend. Rolls et al. [21] showed that larger portion sizes lead to greater energy intake regardless of serving method. The energy expenditure of older children may be higher; therefore a larger portion size prevents negative energy balance and nutrition/health problems associated with it.

That carbohydrate was the main source of energy from the school meals with protein and fat making similar contributions to energy intake was expected. This is necessary to provide readily available energy for school work. Carbohydrates (sugars and starches) provide energy to cells in the body particularly the brain which is a glucose-dependent organ [26]. It also ensures that protein is spared for the function of growth, repair and maintenance of body tissues. The percentage of carbohydrate, fat and protein contributing to energy intake is in line with the dietary guidelines that $45-65 \%$ of energy be supplied by carbohydrate, $25-40 \%$ by fat and $10-$ $35 \%$ by protein [26]. However, the value suggests the need to increase fat intake.

\section{Contribution of the school meals to energy and nutrient intakes of the pupils}

School meals should provide at least one third (an equivalent of $33.3 \%$ ) of the daily recommended nutrient intake (RNI) for energy, protein and other nutrients [27]. The foods consumed by school children in these schools provided more than one third of the RNI for protein, zinc, vitamins $\mathrm{A}$ and $\mathrm{C}$ but failed to meet a third of the RNI for calcium, iron and energy. These findings are in agreement with the outcome of other researches. Nelson et al. [28] showed that 4-18-year-old pupils in England who received free school meals derived a significantly greater proportion of their daily energy and nutrient intakes from their school meals than those who did not have a free school meal. School canteen lunches provided the most nutritious lunch for Scottish school children, with street lunches providing the least nutritious lunch [29]. A study by Owusu et al. [30] in Ghana also showed that the meals provided by Non-Governmental School Feeding Programme (NSFP) had larger portion sizes and contributed 28 and $24.6 \%$ to energy and protein intakes of the children, respectively. Other researchers [31-33] have reported similar findings.

The inadequate contribution made by the foods to energy, calcium and iron requirements of the school children in the 3 schools was in agreement with the report of Nelson et al. [28] who reported that school meals failed to make good the shortfalls in daily intakes of calcium, iron, zinc, and vitamin A. Our finding was attributed to the portion sizes given the pupils which were not nutrient dense enough to provide the required one third of the energy requirement. Besides, we found that only milk and yogurt provided over $100 \mathrm{mg}$ calcium per $100 \mathrm{~g}$ suggesting that a larger quantity and frequency of 
Table 4 Percentage contribution of school meals to RNI of the school children in the three schools

\begin{tabular}{|c|c|c|c|c|c|c|c|c|}
\hline Variables & Age groups & Energy (Kcal) & Protein (g) & Vitamin A (RE) & Vitamin C (mg) & Calcium (mg) & Iron (mg) & Zinc (mg) \\
\hline \multicolumn{9}{|l|}{ Eke Central School } \\
\hline Mean daily intake & $2-5$ years & 357.01 & 20.45 & 266.18 & 11.45 & 171.15 & 1.85 & 3.34 \\
\hline $\begin{array}{l}\text { FAO/WHO/UNU } \\
\text { Requirement }\end{array}$ & & 1550 & 17.5 & 200 & 30 & 600 & 9 & 4.8 \\
\hline$\%$ contribution & & 23.0 & 116.9 & 133.1 & 38.2 & 28.5 & 20.6 & 69.6 \\
\hline Mean daily intake & 6- 9 years & 410.58 & 23.47 & 300.78 & 13.07 & 193.79 & 1.88 & 3.57 \\
\hline $\begin{array}{l}\text { FAO/WHO/UNU } \\
\text { Requirement }\end{array}$ & & 1950 & 27 & 200 & 35 & 700 & 16 & 5.6 \\
\hline$\%$ contribution & & 21.1 & 86.9 & 150.4 & 37.3 & 27.6 & 11.8 & 63.8 \\
\hline Mean daily intake & $10-14$ years & 439.24 & 26.80 & 330.71 & 15.12 & 212.61 & 2.08 & 4.09 \\
\hline $\begin{array}{l}\text { FAO/WHO/UNU } \\
\text { Requirement }\end{array}$ & M & 2200 & 34 & 400 & 40 & 1300 & 16 & 8.6 \\
\hline$\%$ contribution & & 19.9 & 78.8 & 82.7 & 37.8 & 16.3 & 13.0 & 47.5 \\
\hline $\begin{array}{l}\text { FAO/WHO/UNU } \\
\text { Requirement }\end{array}$ & $\mathrm{F}$ & 1950 & 36 & 400 & 40 & 1300 & 16 & 7.2 \\
\hline$\%$ contribution & & 22.5 & 74.4 & 82.7 & 37.8 & 16.3 & 13.0 & 56.8 \\
\hline Mean daily intake & $15-18$ years & 466.09 & 27.10 & 335.82 & 15.23 & 215.81 & 2.09 & 4.11 \\
\hline $\begin{array}{l}\mathrm{FAO} / \mathrm{WHO} / \mathrm{UNU} \\
\text { Requirement }\end{array}$ & M & 2850 & 47 & 400 & 40 & 1300 & 15 & 8.6 \\
\hline$\%$ contribution & & 16.4 & 57.7 & 83.9 & 38.1 & 16.6 & 13.9 & 47.8 \\
\hline $\begin{array}{l}\mathrm{FAO} \text { WHO/UNU } \\
\text { Requirement }\end{array}$ & $\mathrm{F}$ & 2150 & 47 & 400 & 40 & 1300 & 29 & 7.2 \\
\hline$\%$ contribution & & 21.7 & 57.7 & 83.9 & 38.1 & 16.6 & 7.2 & 57.1 \\
\hline \multicolumn{9}{|l|}{$\begin{array}{l}\text { Oma-Eke Community } \\
\text { Primary School }\end{array}$} \\
\hline Mean daily intake & $2-5$ years & 369.43 & 18.81 & 261.48 & 12.64 & 154.70 & 1.41 & 4.23 \\
\hline $\begin{array}{l}\mathrm{FAO} / \mathrm{WHO} / \mathrm{UNU} \\
\text { Requirement }\end{array}$ & & 1550 & 17.50 & 200 & 30 & 600 & 9 & 4.8 \\
\hline$\%$ contribution & & 23.8 & 107.0 & 130.1 & 42.0 & 25.2 & 15.7 & 88.0 \\
\hline Mean daily intake & $6-9$ years & 465.42 & 22.90 & 318.98 & 16.01 & 176.84 & 1.62 & 5.20 \\
\hline $\begin{array}{l}\mathrm{FAO} \text { WHO/UNU } \\
\text { Requirement }\end{array}$ & & 1950 & 27 & 200 & 35 & 700 & 16 & 5.6 \\
\hline$\%$ contribution & & 23.9 & 84.8 & 159.5 & 45.7 & 25.3 & 10.1 & 92.9 \\
\hline Mean daily intake & $10-14$ years & 497.42 & 25.10 & 338.74 & 17.79 & 188.99 & 1.73 & 5.90 \\
\hline $\begin{array}{l}\mathrm{FAO} / \mathrm{WHO} / \mathrm{NU} \\
\text { Requirement }\end{array}$ & M & 2200 & 34 & 400 & 40 & 1300 & 16 & 8.6 \\
\hline$\%$ contribution & & 22.6 & 73.8 & 84.7 & 44.5 & 14.5 & 10.8 & 68.6 \\
\hline $\begin{array}{l}\mathrm{FAO} / \mathrm{WHO} / \mathrm{UNU} \\
\text { Requirement }\end{array}$ & $\mathrm{F}$ & 1950 & 36 & 400 & 40 & 1300 & 16 & 7.2 \\
\hline$\%$ contribution & & 25.5 & 69.7 & 84.7 & 44.5 & 14.5 & 10.8 & 81.9 \\
\hline Mean daily intake & $15-18$ years & 497.87 & 25.10 & 353.75 & 17.68 & 190.60 & 1.72 & 5.82 \\
\hline $\begin{array}{l}\text { FAO/WHO/UNU } \\
\text { Requirement }\end{array}$ & M & 2850 & 47 & 400 & 40 & 1300 & 15 & 8.6 \\
\hline$\%$ contribution & & 17.5 & 53.4 & 88.4 & 44.2 & 14.6 & 11.5 & 67.6 \\
\hline $\begin{array}{l}\mathrm{FAO} / \mathrm{WHO} / \mathrm{NU} \\
\text { Requirement }\end{array}$ & F & 2150 & 47 & 400 & 40 & 1300 & 29 & 8.6 \\
\hline$\%$ contribution & & 23.0 & 53.4 & 88.4 & 44.2 & 14.6 & 5.9 & 67.6 \\
\hline
\end{tabular}


Table 4 Percentage contribution of school meals to RNI of the school children in the three schools (Continued)

\begin{tabular}{|c|c|c|c|c|c|c|c|c|}
\hline Variables & Age groups & Energy (Kcal) & Protein (g) & Vitamin A (RE) & Vitamin C (mg) & Calcium (mg) & Iron (mg) & Zinc (mg) \\
\hline \multicolumn{9}{|c|}{$\begin{array}{l}\text { Abatete Central/Salvation } \\
\text { Primary School }\end{array}$} \\
\hline Mean daily intake & $2-5$ years & 359.82 & 18.11 & 222.75 & 13.54 & 132.90 & 1.74 & 2.10 \\
\hline $\begin{array}{l}\mathrm{FAO} / \mathrm{WHO} / \mathrm{NNU} \\
\text { Requirement }\end{array}$ & & 1550 & 17.5 & 200 & 30 & 600 & 9 & 4.8 \\
\hline$\%$ contribution & & 23.2 & 103.1 & 111.3 & 45.1 & 22.2 & 19.3 & 43.8 \\
\hline Mean daily intake & $6-9$ years & 434.14 & 22.33 & 254.84 & 15.28 & 159.98 & 2.08 & 2.54 \\
\hline $\begin{array}{l}\mathrm{FAO} / \mathrm{WHO} / \mathrm{UNU} \\
\text { Requirement }\end{array}$ & & 1950 & 27 & 200 & 35 & 700 & 16 & 5.6 \\
\hline$\%$ contribution & & 22.3 & 82.7 & 127.4 & 43.7 & 22.8 & 13.0 & 45.4 \\
\hline Mean daily intake & $10-14$ years & 473.18 & 24.43 & 265.70 & 17.87 & 171.18 & 2.14 & 2.79 \\
\hline $\begin{array}{l}\mathrm{FAO} / \mathrm{WHO} / \mathrm{UNU} \\
\text { Requirement }\end{array}$ & M & 2200 & 34 & 400 & 40 & 1300 & 16 & 8.6 \\
\hline$\%$ contribution & & 21.5 & 71.9 & 66.4 & 44.6 & 13.2 & 13.4 & 38.8 \\
\hline $\begin{array}{l}\mathrm{FAO} / \mathrm{WHO} / \mathrm{UNU} \\
\text { Requirement }\end{array}$ & $\mathrm{F}$ & 1950 & 36 & 400 & 40 & 1300 & 16 & 7.2 \\
\hline$\%$ contribution & & 24.3 & 67.9 & 66.4 & 44.6 & 13.2 & 13.4 & 38.8 \\
\hline Mean daily intake & $15-18$ years & 513.72 & 27.27 & 264.16 & 17.12 & 172.24 & 2.16 & 3.02 \\
\hline $\begin{array}{l}\mathrm{FAO} / \mathrm{WHO} / \mathrm{UNU} \\
\text { Requirement }\end{array}$ & M & 2850 & 47 & 400 & 40 & 1300 & 15 & 8.6 \\
\hline$\%$ contribution & & 18.0 & 58.0 & 66.0 & 42.8 & 13.3 & 14.4 & 35.1 \\
\hline $\begin{array}{l}\mathrm{FAO} / \mathrm{WHO} / \mathrm{UNU} \\
\text { Requirement }\end{array}$ & $\mathrm{F}$ & 2150 & 47 & 400 & 40 & 1300 & 29 & 7.2 \\
\hline$\%$ contribution & & 23.9 & 58.0 & 66.0 & 42.8 & 13.3 & 7.4 & 41.9 \\
\hline
\end{tabular}

Source: Energy and protein requirements: Report of a joint FAO/WHO/UNU expert consultation. Technical report series (724).WHO, Geneva,(1985)

Iron requirement: FAO report no 23 (1988). Requirements of vitamin A, calcium, iron and zinc, FAO/WHO report no 23 (1998)

consumption may increase calcium intake. Use of leafy vegetables alone was insufficient. Factors like cost and availability of funds may have affected the portion sizes due to changes in the school menu with the subsequent effect on the energy and nutrient intakes. Cummings et al. [34] affirmed that menu changes resulted in a net reduction of calories, sugar and sodium content of meals offered school children. It implies that other nutrients would be affected as well.

Results from studies like this are important for effective policy formulation and implementation especially where nutrition interventions are required. Previous reports $[1,34]$ have indicated essential roles of school meals in determining adequate health status and general development of school children especially those in areas where school health programme is poorly implemented and school lunch programme not implemented. The limitation of the study is that it focused only on the meals served in PACIEH's schools since these were the only schools where school meal programme was implemented in the two states. Besides, we did not put into consideration the home meals consumed by the children and the bioavailability of the nutrients especially iron and zinc.

\section{Recommendation}

PACIEH should review the school menu to ensure that the quantity of rich sources of calcium and iron are increased. The number of times milk/yogurt and eggs are consumed in a week should be increased. Energy and calcium intake can be increased by use of calcium fortified spreads for bread.

\section{Conclusions}

The meals consumed by the school children in all the three schools where PACIEH implemented school feeding were nutrient dense and provided a third of the recommended daily intakes of protein, zinc, and vitamins $\mathrm{A}$ and $\mathrm{C}$ but failed to meet that of calcium, iron and energy. Calcium and iron are critical nutrients required by school children and calls for a review of the recipes and frequency of consumption of the meals. It is hoped that the results of this study will serve as a guide for future planning of school feeding programmes in Nigeria and more specifically the national Home-grown School Feeding (HGSF) programme being implemented in many States of the Federal Republic of Nigeria. 


\section{Abbreviations}

ENSUBEB: Enugu State Universal Basic Education Board; HAF: Heineken African Foundation; PACIEH: Pan African Community Initiative on Education and Health; PTA: Parents Teachers' Association; RNI: Recommended nutrient intake; SBMC: School based management committee

\section{Acknowledgements}

The researchers are grateful to Heineken African Foundation (HAF) (major funder), ENSUBEB, PACIEH and TruValue for providing funds for the school feeding programme whose foods this study evaluated. We are also grateful to PACIEH and partners for approving this study.

\section{Funding}

The authors declare that they did not receive any funding for this study.

\section{Availability of data and materials}

The dataset of this study are available from the corresponding author on reasonable request.

\section{Authors' contributions}

RNB: Conception, design, analysis and interpretation of data and drafting of the manuscript. PEE: Data collection and interpretation of analysed results, VCA: Data collection, analysis and interpretation of data. HNE: Conception, design and critically revised the manuscript. UVA: Conception and critically revised the manuscript. All authors read and approved the final manuscript for submission.

\section{Ethics approval and consent to participate}

PACIEH, ENSUBEB, Enugu State Ministry of Education, School Based Management Committee (SBMC), the Parents Teachers' Association consented to the study. The children also gave oral consent for their foods to be weighed.

\section{Consent for publication}

PACIEH gave consent for publication.

\section{Competing interests}

All authors declare that they have no competing interests.

\section{Publisher's Note}

Springer Nature remains neutral with regard to jurisdictional claims in published maps and institutional affiliations.

\section{Author details}

'Department of Home Science, Nutrition and Dietetics, University of Nigeria, Nsukka, Nigeria. ${ }^{2}$ Department of Biochemistry (Human Nutrition and Dietetics Unit), University of Calabar, Calabar, Nigeria. ${ }^{3}$ Pan African Community Initiative on Education and Health (PACIEH), Enugu, Canada.

Received: 8 March 2017 Accepted: 12 February 2018

\section{Published online: 21 February 2018}

\section{References}

1. Bundy D, Burbano C, Grosh M, Gelli A, Jukes M, Drake L. Rethinking school feeding: social safety nets, child development, and the education sector Joint publication of the world food Programme and the World Bank. Washington: World Bank; 2009.

2. Bartrina JA, Perez-Rodrigo C. Resources for a healthy diet: school meals. Br J Nutr. 2006:96(S1):S78-81. 10.1079.BJN20061705

3. Osisanya JO, Peters AA, Anyafulu AM, Ogbonnaya JA, Akhimie DO. Food fads and taboos affecting the eating habits of adolescent girls in selected secondary schools in Lagos state. Nig J Nutr Sci. 2008;29(1):135-42.

4. Ukegbu PO. Breakfast eating habits and nutritional status of primary school children in Orumba north LGA of Anambra state of Nigeria. Mal J Nutr. 2015;21:299-307

5. Ugochukwu EF, Onubogu CU, Edokwe ES, Okeke KN. Nutritional contents of lunch packs of primary school children in Nnewi, Nigeria. Ann Med Health Sci Res. 2011;4(Suppl 2):S108-14. https://doi.org/10.4103/2141-9248.138024.

6. Ejekwu AD, Ene-Obong HN, Oguizu OJ. Nutritional status and cognitive performance among children aged 5 - 12 years from urban and rural areas of Enugu state, Nigeria. Afr J Psychol Stud Soc Issues. 2012;15(2):481-96.
7. Nwamara JU, Otitoju O, Otitoju GTO, Emewulu CUD. lodine and nutritional status of primary school children in a Nigerian community Okpuje, in Nsukka LGA, Enugu state, Nigeria. Pharm Lett. 2015;7(7):271-80.

8. Nwabueze AS, llika AL, Azuike EC, Nwabueze NC, Obi KM, Enwonwu KG, Aniagboso CC, Ezenyeaku CA, Ajator CC, Azuike ED. Assessment of nutritional status among primary school pupils in Rural and urban areas of Anambra state. Eur J Prev Med. 2015;3(2):34-8. https://doi.org/10.11648/j. ejpm.20150302.14

9. Olanipekin TO, Obatolu VA, Fasoyiro SB, Ogunba BO. Assessment of nutritional status of primary school children in Ibadan, south-West Nigeria. Nutr Food Sci. 2012:42(6):390-6.

10. Adegun JA, Ajayi-Vincent $O B$, Alebiosu EO. Differences in the nutritional status of young school children from public and private owned primary schools in Ekiti state, Nigeria. Eur Sci J. 2013;9(7):32-7.

11. Opara KN, Udoidung NI, Opara DC, Okon OE, Edosomwan EU, Anietie JU. The impact of intestinal parasitic infections on the nutritional status of rural and urban school-aged children in Nigeria. Int J MCH AIDS. 2012;1(1):73-82.

12. Onimawo IA, Ukegbu PO, Asumugha VU, Anyika JU, Okudu H, Echendu CA, Nkwoala C, Emebu P. Assessment of anaemia and iron status of school age children (aged 7_12 years) in rural communities of Abia state, Nigeria. Afr J Food Agric Nutr Dev. 2010;10(5):2570-86.

13. Ayogu RNB, Okafor AM, Ene-Obong HN. Iron status of school children 6 15 years and associated factors in rural Nigeria. Food Nutr Res. 2015;59: 26223. https://doi.org/10.3402/fnr.v59.26223

14. Akeredolu IA, Oguntona BE, Okafor C, Osisanya OJ. Iron, zinc and copper malnutrition among primary school children in Lagos, Nigeria. Food Nutr Sci. 2011;2:1063-70. https://doi.org/10.4236/fns.2011.210142.

15. CDI Study Group. Community-directed interventions for priority health problems in Africa: results of a multi-country study. Bull World Health Org. 2010;88(7):509-18

16. Stadlmayr B, Charrondiere R, Victor N, Enujiugha VN, Bayili RG, Fagbohoun EG, Samb B, Addy P, Barikmo I, Ouattara F, Oshaug A, Akinyele I, Annor NA, Bomfeh K, Ene-Obong H, Smith IF, Thiam I, Burlingame B. West Africa food composition table. Rome: Food and Agriculture Organization of the United Nations; 2012. http://www.fao.org/docrep/015/i2698b/i2698b00.pdf. Accessed 15 Dec 2016

17. Association of Analytical Chemists. Official methods of analysis. Washington DC: Association of Official Analytical Chemists; 2010.

18. Food and Agriculture Organization of the United Nations. Food energymethods of analysis and conversion factors. FAO food and nutrition paper 77. Report of technical workshop (Rome, 3-6 December, 2002), Rome: food and Agriculture Organization; 2003. ftp://ftp.fao.org/docrep/fao/006/y5022e/ y5022e00.pdf. Accessed 12 Dec 2015.

19. Food and Agriculture Organization. Nutritional benefits of pulses. Rome: FAO; 2016. http://www.fao.org/3/a-i5384e.pdf. Accessed 22 Dec 2016.

20. Mudryj AN, Yu N, Aukema HM. Nutritional and health benefits of pulses. Appl Physiol Nutr Metab. 2014;39(11):1197-11204. https://doi.org/10.1139/ $1 \mathrm{pnm}-2013-0557$.

21. Rolls BJ, Engell D, Birch LL. Serving portion size influences 5-year-old but not 3-year old children's food intakes. J Am Diet Assoc. 2000;100(2):232-4.

22. Sanusi RA, Adebiyi AE. Proximate and mineral composition of commonly consumed foods in Nigeria. Nig J Nutr Sci. 2009;30(2):54-63.

23. Okeke EC,Ene-Obong HN, Uzuegbunam A, Ozioko A, Umeh S, Chukwuone $\mathrm{N}$. The Igbo traditional food system documentation in four states in southern Nigeria. In: Kuhnlein HV, Erasmus B, Spigelski D (Ed.). Indigenous people food systems: the many dimensions of culture, diversity and environment for nutrition and health. Rome: FAO and Centre for Indigenous Peoples Nutrition and Environment; 2009: 251 - 281 http:// www.fao.org/docrep/012/i0370e/i0370e00.htm. Accessed 14 Nov 2016.

24. Ene-Obong HN. Eating right. Calabar: University of Calabar Press; 2001.

25. Gomez-Pinilla F. Brain foods: the effects of nutrients on brain function. Nat Rev Neurosci. 2008;9(7):568-78. https://doi.org/10.1038/nrn2421.

26. Health and Medicine Division (HMD). Dietary reference intakes for energy, carbohydrate, fibre, fat, fatty acids, cholesterol, protein, and amino acids. Washington DC: National Academies Press, 2002. DOI https://doi.org/10. 17226/10490. https://www.nationalacademies.org/hmd/Reports/2002/ Dietary-Reference-Intakes-for-Energy-Carbohydrate-Fiber-Fat-Fatty-AcidsCholesterol-Protein-and-Amino-Acids.aspx. Accessed 22 Nov 2016.

27. Federal Ministry of Education, Nigeria. Implementation guidelines on National School Health Programme. Sports and health division, Federal Ministry of education; 2006. https://www.unicef.org/nigeria/NG resources implementationschoolhealthprog.pdf. Accessed 14 Nov 2016. 
28. Nelson M, Lowes K, Hwang V. The contribution of school meals to food composition and nutrient intakes of young people aged $4-18$ years in England. Pub Health Nutr. 2007;10(7):652-62. https://doi.org/10.1017/ S1368980007382529

29. Norris C, Clapham M, Davidson I, Wyness L. School meal contribution to nutrient intake amongst 11-14 years old Scottish school children. EC Nutr. 2016;4(2):836-44.

30. Owusu JS, Colecraft E, Aryeetey R, Vaccarol JA, Huffman F. Contribution of school meals to nutrient intakes of school-age children enrolled in two feeding programmes in Ghana. Fed Am Societies Exp Biol (FASEB) J. 2016; 30(1):S669.3.

31. Stevens $L$, Nelson M. The contribution of school meals and packed lunch to food consumption and nutrient intakes in UK primary school children from a low income population. J Human Nutr Diet. 2011;24(3):223-32.

32. Rees GA, Richards CJ, Gregory J. Food and nutrient intakes of primary school children: a comparison of school meals and packed lunches. J Human Nutr Diet. 2008;21(5):420-7. https://doi.org/10.1111/j.1365-277X. 2008.00885.x.

33. Osowski CP, Lindroos AK, Barbieri HE, Becker W. The contribution of school meals to energy and nutrient intake of Swedish children in relation to dietary guidelines. Food Nutr Res. 2015;59:27563. https://doi.org/10.3402/fnr. v59.27563

34. Cummings PL, Welch SB, Mason M, Burbage L, Kwon S, Kuo T. Nutrient content of school meals before and after implementation of nutrition recommendations in five school districts across two U.S. counties. Prev Med. 2014;67(Suppl 1):S21-7.

\section{Submit your next manuscript to BioMed Central and we will help you at every step:}

- We accept pre-submission inquiries

- Our selector tool helps you to find the most relevant journal

- We provide round the clock customer support

- Convenient online submission

- Thorough peer review

- Inclusion in PubMed and all major indexing services

- Maximum visibility for your research

Submit your manuscript at www.biomedcentral.com/submit 